\title{
POLITICAL ETHNICITY AND MUSLIMS AROUND THE WORLD: A SOCIOLOGICAL PERSPECTIVE
}

\author{
Mariam Bibi \\ Assistant Professor \\ Jinnah University for women \\ Karachi - Pakistan \\ maryam.shah@gmail.com \\ Dr. Tansif Ur Rehman \\ Visiting Faculty, Department of Criminology, \\ University of Karachi \\ Karachi - Pakistan, \\ tansif@live.com \\ Dr. Nuzhat Akram \\ Education Officer, \\ Pakistan Marine Academy, \\ Karachi. \\ dr.nuzhatakram@gmail.com
}

\begin{abstract}
Political ethnicity has remained a core analytical aspect for individuals, politicians, and scholars regarding their substantial roles in society, economy, politics, and religion. Under some extensive measures, the study of ethnic politics is not as new as it seems. Eventually, the politics revolving around the state arena started from the advent of the imperial rules of empires vesting towards the voyage of obtaining substantial interest and economic gain, which surprisingly oriented the turmoil of class differences and other racial and religious conflicts over the decades. Furthermore, the concept of ethnic politics has often changed its dimensional paths with the unification of revolutionary, ethnic groups, which conjugates into never-ending movements with incessant consequences. Wherever ethnic politics tend to exist, world politics' climax drifts apart because a humanitarian approach does not just infer
\end{abstract}




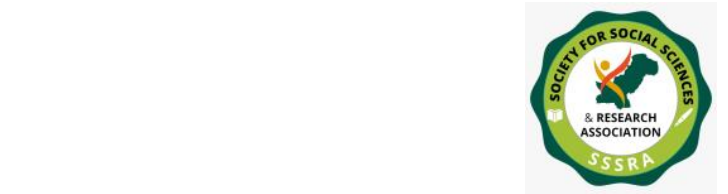

Pak. Journal of Int'L Affairs, Vol 4, Issue 1 (2021)

Political Ethnicity and Muslims ...

superficial societal changes. There is a common assumption, and the West's misconception is effective than the East, and Muslims are not much advanced as they often exhibit incapacity. Unlike other ideologies and civilizations, Islam, from its very start, acknowledged the sociopolitical rights and obligations of people. The view of Islam for individuals is the total submission to Allah's need, not subjugation to people's will. The study focusses on the issues of Muslim political ethnicities around the world in the sociological point of view.

Keywords: Arabs, EU, Islamophobia, political ethnicity, Myanmar, West

\section{Introduction}

The study of ethnic politics comes under variant and exclusive authorities as it underwent various studies and analytical approaches within the international community. Under some extensive measures, the study of ethnic politics is not as new as it seems. The politics revolving around the state arena started from the advent of imperial rules of empires vesting towards the voyage of obtaining substantial interest and economic gain, which surprisingly oriented the turmoil of class differences along with other racial and religious conflicts over decades.

Furthermore, the concept of ethnic politics has often changed its dimensional paths with the unification of revolutionary ethnic groups, which conjugates into a neverending movement with incessant consequences. Wherever ethnic politics exist, world politics drift apart because humanitarianism demands egalitarian reforms and social changes.

\section{Historical Advents of Islamic Ethnic Politics in Arab}

Quranic verses related to ethnic and racial diaphragm also justify the variation of races living in a multidimensional society. On account of Quranic description on verse variants, one of the verse has dignified the differences among humanity and race on the perception of the language they speak enlisted in (Quran, 30: 22) multilateral acknowledgment of kinds and linguistic approaches of recognition of a tribe of men in non-other than Allah's divine process. Another verse significantly identifies the importance of gender equality to be extensively equal and without bias from the other race, they meet in their tribunal conquest and journey and also focus their attention on the supremacy of Allah at the same time. (Quran 49:13) It's pretty much similar to the sermon that Muhammad's peace upon him made during His last sermon. There is no 


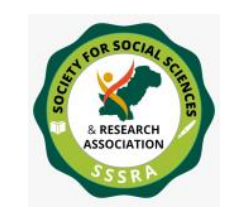

Political Ethnicity and Muslims ...

specific racial or ethnic stratification and prejudice in Quran "You are indeed the best community that has ever been brought forth for [the good of] humanity (Qur'an, 3:110).

So at its center is the faith and connection of an astonished follower. When the Muslims traveled to the Arabian Peninsula's boundaries defining that specific cult of land, they were massively divided under the hierarchy of racial and ethnic dissonance. Sunnah and Hades tend with regards to confirming Arab ethnic dominance inside Islam based on Islam openly declared the irrelevance of superiority based on color in the sight of Allah.

Despite the diversity of Sunnah, the moral view of dominance in religious writings echoed the Quran's insistence that piety takes priority over racial as well as ethnic backgrounds. The crucial practice of traditional and normative believes stands under the domain of Islamic virtues Islamic laws and ethics are relevant to spiritual morality (Bethmann, 2020). In Islam, slavery is not an option related to ethnic minorities, and Islam demographically restricts the process of prostitution among prisoners and slaves under their Muslim identity. Slavery was not related to skin color within the Muslim world, as it came about within the Western world (Mura, 2015).

The dilemma lies in the fact that Muslims do not defy any specific skin color if Islamic theology and law defy any particular skin color. Literature is abundant by Muslims, wherein Muslim scholars argue regarding characteristics and moral qualities of human beings of different races and ethnicity. Throughout the Islamic era, Muslim society's growing diversity has been a competitive aspect in the contemporary era of racial and ethnic hierarchies (De O'leary, 2019).

The $10^{\text {th }}$ century writer Ahmad Ibn Muhammad Ibn Al-Faqih Al-Hamadani wrote that light brown color became the most appropriate and suitable color for the Iraqis. In the Ummah, racial stereotypes, ranking, and generalization often, underwent the acceptance of believers. Through the passage of time, the Arab genocide created a setback. Shoaib, a college of Iranian Muslim writers who were crucial regarding social and literary movements in the $9^{\text {th }}$ and $10^{\text {th }}$ centuries, praised the most delicate and civilized social customs accompanied by Iranians and challenged them to count on Arab superiority over other Muslims. (Haddad, 2011).

Pre-Islamic Iran's wealthy ancient lifestyle confirms the wealth and charismatic persona of the Persian language as compared to Arabic. The most paralyzing feel of racial segregation turned into diagnosis in medieval Egypt, which praised Egypt's famous fertility, the USA's historical position as a sample of innovational cultural leg and 


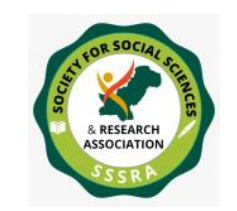

Pak. Journal of Int'L Affairs, Vol 4, Issue 1 (2021)

Political Ethnicity and Muslims ...

acknowledgments, later on, Egyptian intervention and importance in performing as an embankment of Islam under the opposition the crusaders and Mongol empires conquest. (Encyclopedia.com, 2020).

Ham's curse's biblical story entered Muslim mythology and shapes the racial premises of African conventionalization., appearances outcast and morally flawed, which embodied an awful basis in medieval Muslim literature (Mura, 2015). Photos associated with unique ethnic corporations can also expand as social and political situations alternate. For this reason, the Turkish people first acknowledged the Muslim's ideological identity, generally as arms prisoners, to start with homogeneous savages. As Turkish agencies transformed to Sunni Islam and entered the international Muslim community in huge numbers and eventually became politically dominant, the prevailing scenario was that the Turks first became anti-Shiites, then champions of Islam in opposition to the pagan Mongols, and in the end, ruthless foreigners (Bethmann, 2020).

The growing prominence of ethnic identification in Muslims in the 19th and 20th century and the development of language-based nationalist movements was a brand new phenomenon that combined best-preconceived notions of race and ethnicity (De O'Leary, 2019). It impacted the social and political connections of nationalists' formatives and concepts from the north that created Arabian Muslims, Turks, Iranian's, and other Islamic populace nationalism (Vacca, 2017). Arab monuments their typographical and historical journey and legends under the module of Islam and religion premises; Turk's emphasis on political recognitions for future control and power. Iranian glorifies the historical advents of accomplishment, previously accounted for their ethnic attitudes and obsoletes, ethnic agencies had been reinforced and served as a catalytic reactor for present-day ethnic idealism (Encyclopedia.com, 2020).

Further, present-day racial nationalism spread by the racist ideology that evolved from Europe during the 19th and 20th centuries. Contemporary nationalism among the Muslim population predates Muslim awareness of modern racist ideology, as it had been initiated for other motives. One such area in which racist questioning had a transient effect became Iran, i.e., Aryan (Vacca, 2017).

Wherein, the worldwide prominence of Germany's fellow Aryans within the early 20th century affected Iranian self-concept and perception of others. Contemporary Arab animosity towards Jews (Arab anti-Semitism, i.e., it is in itself an eminent cause for Arabic sentimental linguistic) appeared in the Scio-political contempt of war with Israel, a racist ideology. It finds support from the occasional negative references in Quran. Thus 


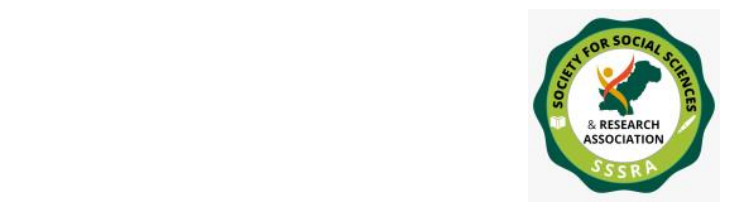

Political Ethnicity and Muslims ...

it facilitated a familiarity with European anti-Semitic paths exclusive of Zion's protocols (Encyclopedia.com, 2020).

During the latter part of the 20th century, the most crucial ethnic nationalism started to be overthrown via a feel of identification based on religion and a characteristic defined on the idea of faith in preference to race (Bethmann, 2020). Islam is a unique phenomenon that re-emphasizes religious aviation primarily based on verbal and communicational space, race, and locality. The foundation of nationalist intuitions of Islamic representatives started a purge of influence over the entire Ummah from overseas. Its final course is to denounce racial nationalism as it is alien to Islam. However, unfortunately, this has not yet been fully exercised (Hopkins \& Fiaz, 2002)

\section{Muslim Communities in Europe and Western World}

Muslims face segregation in a broad scope of European settings, particularly when searching for work, work, or attempting to get to public or private administrations. Muslims are an assorted blend of races, strict affiliations, philosophical convictions, political inspirations, ordinary propensities, dialects, and social customs. (Hashas, 2019).

According to the Pew Research Center, around 20 million Muslims live in the EU, about $4 \%$ of the EU's population - with huge contrasts between and inside EU states. France and Germany have the most prominent Muslim population, i.e., about 4.7 and 2.6 million. Almost $46 \%$ of all Muslims in the EU live in these two countries (European Union Agency for Fundamental Rights, 2017).

As individuals from an ethnic minority group and a strict minority, females face issues with non-Muslims regarding covering their heads. The point of wearing a headscarf by and large in Europe has a long relationship to discrimination and prejudice (Hashmi, 2003).

In September 1988, two Manchester students in Britain were denied the consent to wear a headscarf on security grounds. The Commission for Racial Equality clarified that this was circuitous racial separation and that young females were not permitted to wear a headscarf. In Britain, respective law is covered under the Race Relations Act of 1976 (Modood, 1990).

It was inferred that Muslims should not be an ethnic gathering with shared social, semantic, or geographical aspects; this was incompletely a flawed decision based on a biased and irrational assessment. Along these lines, Muslims were not given the 


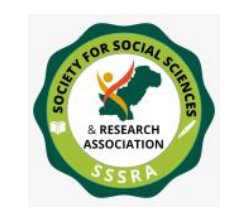

Pak. Journal of Int'L Affairs, Vol 4, Issue 1 (2021)

Political Ethnicity and Muslims ...

psychosocial assurance that Jews and Sikhs possessed. Manchester still is a disputable territory among Muslims for the past three decades (Hashas, 2019).

In the Netherlands, during 1993 and 1994, wearing a headscarf was considered an issue at the workplace and educational institutions. In Germany, a young Muslim female was expelled from physical training sessions since she refused to be co-instructed during swimming lessons. (Hashmi, 2003).

\section{Islamophobia and European Union Assault over Muslim Women}

Muslim females often face three types of fines in business in the EU; sex fines, racial fines, and strict fines. Segregation in the work market is frequently connected with 'Muslims' and particularly female Muslim garments. The headscarf is an extra obstruction in acquiring and sustaining a job. In Germany, $18 \%$ of organizations welcomed candidates with German names for an interview, while $13 \%$ welcomed candidates with Turkish names. CV for applications from Muslim females with a headscarf in the photograph received just 3\% of organizations invitations for an interview (European Network Against Racism, 2020).

In many countries, Muslim females are more inclined to loathe and discourse than Muslim men, mainly because they wear a headscarf. Muslim women are exposed to dangers, threats, savagery, and physical as well as online attacks (Pauly, 2016).

For instance, in the Netherlands in 2019 , over $90 \%$ of casualties regarding racism and religious hatred were related to Islamophobia and primarily carried against Muslim females. In France during 2019, around $81.5 \%$ of womenwho faced brutality were wearing a headscarf. (European Network Against Racism, 2020).In the UK, almost all attacks are carried out on Muslim women. Verbal and physical savagery is regularly blended, just as bigoted and sexual affronts, and episodes occur mostly in daylight and public places (Nandi \& Platt, 2018).

Biases and wrong portrayal of Muslim women are being spread by the media, public, and even individual legislators. This negative spotlight on Muslim women in the media and political discussions and interviews likewise contribute to unfair practices and viciousness (Pauly, 2016).

"Muslim females are the object of segregation and savagery since they are females and Muslim, yet nothing has been done to address the numerous issues they face," said ENAR pioneer Sarah Isla. "If the EU underpins the battle against sexual 


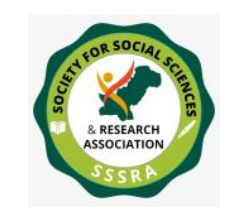

Pak. Journal of Int'L Affairs, Vol 4, Issue 1 (2021)

Political Ethnicity and Muslims ...

orientation, equity, and prejudice against Muslim women, it must not neglect them" (European Network against Racism, 2020).

\section{Rohingya Conflict and Muslim Minority}

In August 2017, the Myanmar military deported hundreds of Rohingya Muslims to Bangladesh who had fled across the border in horrific repression. Myanmar's government then risked everything they could to carry out a naval and military attack, which is often defined as a contemporary example of identity crisis and extinction. In January 2020, Myanmar's judiciary delegated the Buddhist populace's to act as a protectorate over the Rohingyan minorities. However, Myanmar has combated with the Rohingya militants and refuses to target civilians. Aung San Suu Kyi leadership towards the onset of humanitarian contingency has faced numerous denial and unauthorized delegations, against the allegation of genocides (BBC News, 2020).

Rohingya is a diverse identity that resided in Myanmar. As 2017 drew to a close turn, more than one million Rohingyan in Myanmar contributes to being the largest ethnic civilization. Apart from that Muslim minorities resided in Rohingya are estimated to be a lump sum civilization Muslims in Myanmar, in Rakhine province. Having their own language and cultural norms, similar to the Arab decedent they claim to be, coming to the region for generations (Human Rights Watch, 2018).

However, Myanmar, a predominantly Buddhist country, denied Rohingya citizenship, even excluded them from the 2014 census; they see them as illegal immigrants from Bangladesh. In the 1970s, the Rohingya settled in significant numbers throughout the region. Estimates of their numbers are often far superior to formal statistics. Over the past few years, more than a sophisticated disaster, piles of Rohingya have made dangerous journeys from Myanmar to break up communal violence or claim to be abused by the use of security forces. Rohingya refugees often claim they fled to Bangladesh after Buddhist gangs financed by the locals burn down and attack their villages. Rohingyan population of 6700 accounts for 730 children rated under 5 years of age was assumed to be killed in the outrage of violence. (Medecins Sans Frontieres, 2017).

Amnesty International (2018) reports that the Myanmar militant actions towards indigenous rapes and sexual assault over girls and women uncomprehend. Their correspondents noticed the burning of villages staying in the state of Rakhine. Myanmar's officials claim that 400 died in operation against the militants, and it ended on September 5, although independent reporters have evidence that they continued after that date. 


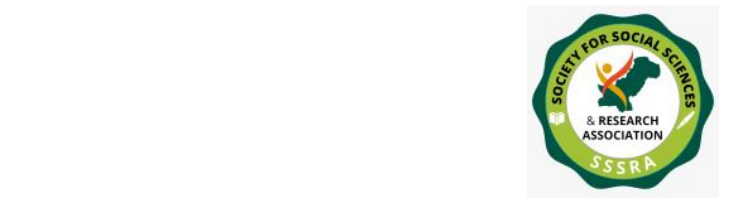

Political Ethnicity and Muslims ...

Since August 2017, approximately 288 villages under the domain of northern Rakhine locality have been demolished by the usage of firecrackers and field fires, according to satellite analysis by Human Rights Watch. Human Rights Watch reports that between August 25 and September 25, 2017, most of the damage in Mandau (a village in Kachin state) was caused by the destruction of several villages after September 25. Myanmar's leader, Aung San Suu Kyi, said the security crackdown was over (Human Rights Watch, 2018).

In August 2018, the UN report accused the Myanmar militants of executing outraged murders and sexual assaults in terms of genocide. In West Africa, a case was registered by the small Muslim-majority in the Gambia along with the filing of an accusation by various Muslim international co-operations speared of Datmadox in Myanmar under military rule' (Amnesty International, 2020).

However, denial against genocide charges was determined by Aung San Suu Kyi, while given a succession in court in December 2019. Despite the denial in January 2020, the court's initial hearing succeed, Myanmar to take urgent action to prevent Rohingya's prostitution and murders. International Court of Justice (ICJ) has the authority to restrain that accusation of deviance and crimes against the humanitarian crisis. Over the month of November 2019, the authorities approved comprehensive research over Myanmar. Although Myanmar has not been a tribunal member, there is a legal jurisdiction within the case because Bangladesh is ICJ's member state where the victims fled (BBC News, 2020).

About half a million of the Rohingya population living in Myanmar, specifically in northern Rakhine state, the UN says that a high risk of hanging over Rohingya in terms of genocidal attacks and warnings. Because Rohingya are present in a refugee camp near Cox's Bazar, the scenario that led to murders, rapes, gang rapes, torture, and other severe violations in 2017 remained unchanged, with investigators accusing Myanmar of failing to heed charges fully and committing genocide. Rakhine State is the site of an ongoing war between the military and rebels of the Buddhist-majority Rakhine ethnic group (BBC News, 2020).

\section{United Nation Resolution of Ethnic Minority Rights}

All states belonging to the United Nations have, per article 56 of the Charter, undertaken an obligation to cooperate with the organization in promoting universal respect and observance of human rights and fundamental freedoms, all without distinction as to race, leg over, language, or religion (UN Charter, art. 55c). This 


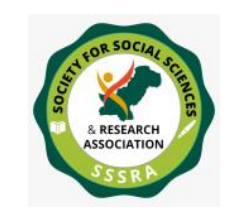

Political Ethnicity and Muslims ...

obligation to cooperate in the prevention of human rights violations extends to all standards adopted by the United Nations in the pitch of human rights.

\section{Conclusion}

Ethnicity and ethnic politics is critical phenomenon of plural societies. In the developing world, ethnic politics is one of the significant motives of internal instability. Ethnicity is an essential function of human identification that manifests differently in distinctive societies. It reflects diversity in the community whose internal concord and stability defend how the ethnic range is accommodated in a nation's pluralistic body and culture. Politics over ethnic aspects has profound consequences, which escalates a complicated class of adversities parallel to individual societies' financial and political balance. The individualistic ideologies have marked profound effects over distinctive racial groups, and ethnic superiority is visible concerning the subject matter. Moreover, the ethnic warfare or traditional forsaking of culturalism with current nationalism has provided fuel to the racial and ethnic debate, which paves into the development of state politics and self-centeredness.

Throughout history, human psychology has manifested deviant features inside innovative societies, and what more stunning is that these manifestations serve as the basis of racial, gender, ancestral, and ethnic identities and inequalities. Ethnicity is undoubtedly a catalyst in uprooting and shattering ordinary momentum and montage of peace between states. Researchers suggest a verifying phenomenon of stability and sociopolitical enhancement regarding customs, citizenship, and responsibilities. There is a common assumption, and the West's misconception is effective than the East, and Muslims are not much advanced as they often exhibit incapacity. Unlike other ideologies and civilizations, Islam, from its very start, acknowledged people's sociopolitical rights and obligations. The view of Islam for individuals is the total submission to Allah's need, not subjugation to people's will.

\section{Recommendations}

1. Countries worldwide have to enact special civil laws to counter the prevailing discriminatory laws against minorities.

2. Countries need to formulate an accessible mechanism thruought which sufferers can file lawsuits virtually (online).

3. Law enforcement agencies and government officials should be trainend to pertain to deal with instances of human rights violations. 
4. An international judicial tracking body should be made to record, follow-up, and publicize rulings with superior minority courts' aid on pertinent issues.

5. Efforts need to be made to put into effect article 7 of the UN Charter, which establishes equality in all citizens' rights and responsibilities.

6. Some existing laws of UN member countries should be modified as it encourages racism and prejudices against minorities.

7. Legal guidelines reinforcing equality need to be promulgated, discriminatory standard policies should be repealed or amended.

8. The nationality law of several countries must be amended to permit minorities to secure their nationality. 


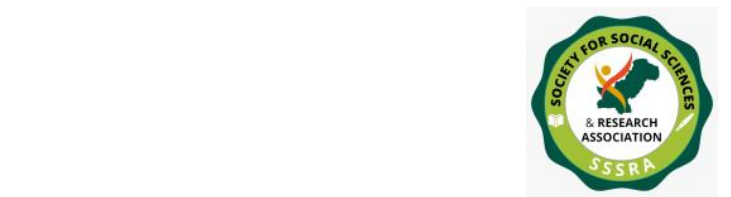

\section{References}

Amnesty International. (2018, May 22). Myanmar: New Evidence Reveals Rohingya Armed Group Massacred Scores in Rakhine State. https://www.amnesty.org/en/latest/news/2018/05/myanmar-new-evidence-revealsrohingya-armed-group-massacred-scores-in-rakhine-state/.

Amnesty International. (2020). Myanmar 2019.https://www.amnesty.org/en/countries/asiaand-the-pacific/Myanmar/report-Myanmar/.

BBC News. (2020, January 23). Myanmar Rohingya: What you need to know about the Crisis. https://www.bbc.com/news/world-asia-41566561.

Bethmann, E. (2020). Bridge to Islam. Routledge. http://doi.org/10.4324/9781003109136.

De O'leary, L. E. (2019). Islam at the Cross Roads: A Brief Survey of the Present Position and Problems of the World of Islam. Routledge. https://doi.org/10.4324/9780367351595.

Encyclopedia.com. (2020). Ethnicity and Race: Islamic views. In New Dictionary of the History of ideas. https://www.encyclopedia.com/history/dictionaries-thesaurusespictures-and-press-releases/ethnicity-and-race-islamic-views.

European Network Against Racism. (2016, May 26). Women are the first to pay the price of Islamophobia in Europe. The Voice of anti Racist Movement in Europe: European Newtwork Against Racism. https://www.enar-eu.org/Women-are-the-first-to-pay-theprice-of-Islamophobia-in-Europe.

European Union Agency for Fundamental Rights. (2017, September 21). Second European Union Minorities and Discrimination Survey. Muslims-Selected Findings. https://fra.europa.eu/sites/default/files/fra_uploads/fra-2017-eu-minorities-surveymuslims-selected-findings_en.pdf.

Haddad, F. (2011). Sectarianism in Iraq: Antagonistic visions of unity. Oxford University Press.

Hashas, M. (2018). The Idea of European Islam: Religion, Ethics, Politics and Perpetual Modernity. Routledge.https://doi.org/10.4324/9781315106397 
Hashmi, N. (2003). From Ethnicity To Religion: The Shifting Identities Of Young Muslims In Britain And France [Doctoral dissertation]. European University Institute Repository. http://aei.pitt.edu/745/1/ICHashmi.pdf

Hopkins, L. \& Fiaz, R. (2002). Understanding Muslim Ethnic Communities in England. Department for Communities and Local Government.

Human Rights Watch. (2018). Myanmar Events of 2018. World Report 2019. https://www.hrw.org/world-report/2019/country-chapters/myanmar-burma.

Médecins Sans Frontieres: Doctors without Borders. (2017, December 12). MSF Surveys Estimate That at least 6,700 Rohingya were killed during the attacks in Myanmar. https://www.msf.org/myanmarbangladesh-msf-surveys-estimate-least-6700-rohingyawere-killed-during-attacks-Myanmar.

Modood, T. (1990). Muslims, Race and Equality in Britain: Some Post-Rushdie Affair Reflections. Third Text, 4(11), 127-134.

Mura, A. (2016). The Symbolic Scenarios of Islamism: A Study in Islamic Political Thought. Routledge. https://doi.org/10.4324/9781315552392.

Nandi, A., \& Platt, L. (2018). The Relationship between political and ethnic identity among UK ethnic minority and majority populations. Journal of Ethnic and Migration Studies, 46(5), 957-979.

Pauly, R.J. (2016). Islam in Europe: Integration or marginalization? Routledge. https://doi.org/10.4324/9781315589961

Vacca, A. (2017). Non-Muslim Provinces Under Early Islam: Islamic Rule and Iranian Legitimacy in Armenia and Caucasian Albania. Cambridge University Press. 